\title{
THE SECOND HALF OF THE READYMADE CENTURY (1964-)
}

\section{Dieter Daniels}

\begin{abstract}
The readymades conceived and selected by Marcel Duchamp between the years 1914-1917 have, with very few exceptions, not survived until the present day as 'original.' A variety of forms, including documentary photos, objects chosen and approved later by Duchamp as well as remakes of the historical objects comprise the readymades' legacy. Duchamp's remakes of his readymades as a limited edition of multiples from 1964, commemorating the 50-year anniversary of his selection of the Bottle Dryer in 1914, mark the beginning of the second half of the "Readymade Century." In contrast to their widespread visibility, the paradoxical "constructedness' of these objects is rarely discussed. The representational impact and the conceptual specificity of these multiples goes far beyond the oeuvre of Marcel Duchamp, and can be seen as a premonition of artistical appropriation strategies from the 1980 s to the present day.
\end{abstract}

\section{KEYWORDS}

Multiple, Remake, Reproduction, Appropriation, Post-readymade

Marcel Duchamp: "But remember, I definitely do not want to create a school of the readymade; far from it."

Jean Antoine: “As a matter of fact, doesn’t your concept of readymades preclude the idea of a school?"

Marcel Duchamp: "Yes, to some extent, but not entirely. But, ultimately, I know there is an inherent danger in the readymade, and that is the ease with which it can be produced. So, if you were to create tens of thousands of readymades per year, that would become extremely monotonous and irritating. So I would recommend restraint in the production of readymades.” 1

(Marcel Duchamp interviewed in 1965) 
Fig. 6.1

Marcel Duchamp, L.H.O.O.Q. or La Joconde, 1964 (replica of 1919 original). Coloured reproduction, heightened with pencil and white gouache, $29.8 \times 20.0 \mathrm{~cm}$. Edition of 38 (35 numbered and 3 not numbered), No. 6 (Arturo Schwartz edition). Norton Simon Museum, Gift of Virginia Dwan. () Association Marcel Duchamp / ADAGP, Paris / Artists Rights Society (ARS).

Fig. 6.2

Constellation of three versions of the Bottle Dryer signed by Duchamp (from 1921, 1960, and a multiple from 1964) as well as a new specimen from the Bazar de l'Hôtel de Ville in Paris, where Duchamp had bought his first Bottle Dryer in 1914. In the foreground: Marcel Duchamp, Trap, 1917/1964. Übrigens sterben immer die anderen: Marcel Duchamp und die Avantgarde seit 1950, Museum Ludwig, Cologne 1988 (curators: Dieter Daniels and Alfred M. Fischer). @Association Duchamp Marcel.
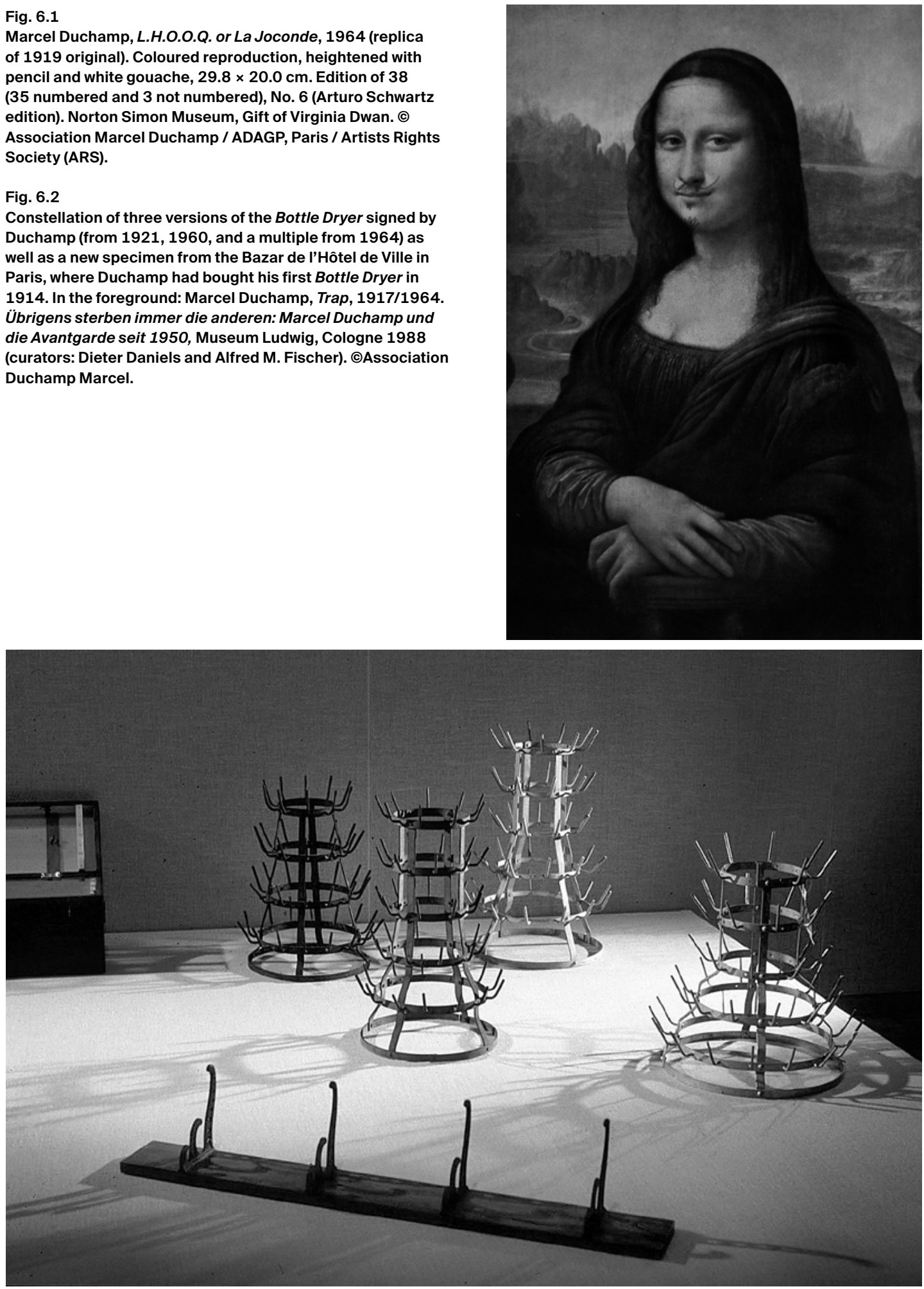
THE SELF-APPROPRIATION OF DUCHAMP:

THE READYMADE MULTIPLES

In interviews from the 1960s, Duchamp emphasized that the readymades were not to be seen as originals, but could at any time be replaced by replicas: "Another aspect of the 'Readymade' is its lack of uniqueness... The replica of a 'Readymade' delivering the same message; in fact, nearly every one of the 'Readymades' existing today is not an original in the conventional sense." 2 This statement can only be applied to pure, unmodified readymades. A readymade rectifié-such as the postcard with a reproduction of the Mona Lisa, to which Duchamp added a thin moustache, a small pointed beard, and the title "L.H.O.O.Q."-definitely carries the status of an original. This status was even authenticated by Duchamp in 1944, when he added a notarial certification on the back: "This is to certify / that this is the original / 'ready made' L.H.O.O.Q. / Paris 1919 / Marcel Duchamp / New York 1944.”3 Aesthetically, the subtly drawn beard of the original from 1919 is very different from the edition produced in 1964 (Fig. 6.1), where Duchamp sketched in the beard 38 times, one for each copy of the edition.

For the pure, unmodified readymade, the status of an original would be meaningless, and it could easily be replaced by an equivalent replica (as long as Duchamp added the inscription). There are basically two possibilities for creating such a replica: one could either buy a similar 'ready-made' product and accept the range of variations within a palette of the same product, or one could produce from raw material an object as close as possible to the original. The fundamental difference between the simple selection of an object and the manual fabrication of a remake has rarely been discussed among Duchamp scholars. For example, of the Bottle Dryer's seven replicas listed in Duchamp's Complete Works, five had been newly bought and two had been recreated. Duchamp signed each of the Bottle Dryers, whose forms varied considerably in 1921, 1936, 1960, 1961, and 1963. Ulf Linde was the first to replicate a single copy of the Bottle Dryer in 1963 for the Duchamp exhibition at the Gallery Burén in Stockholm. In 1964, the edition of multiples produced by Galleria Schwarz followed (Fig. 6.2).4

This edition of “14 Readymades” from 1964 ended Duchamp's practice of freely signing any bottle dryer or urinal, since a contract with Galleria Schwarz obliged him to guarantee exclusivity for the multiples. 5 Their standardized shape, which, according to Arturo Schwarz, had to match the original form, now replaced the previous variety of objects. In this way, Schwarz retroactively accorded the status of an original to the "pure" readymades after 
which the edition was modeled-a status they did not previously have in Duchamp's view. In 1964 one could easily have bought a new 'ready-made' bottle dryer, and yet for the edition of multiples they were specifically produced in a small series, same as the urinal, the snow shovel, the comb, the coat rack, and the hat rack.

There were very different preconditions for the fabrication of each of the remakes. The breadth of variations reached from making a copy of an existing original (comb), through reconstructions after historical photos of the missing originals (urinal, snow shovel, coat rack, hat rack), to constructions without any surviving documents for the original (bottle dryer, typewriter cover). ${ }^{6}$ Schwarz did not address this heterogeneous state of the record, but had professionals draw vertical sections and crosssections for all of the " 14 Readymades," from which the multiples were then produced. ${ }^{7}$ In contrast to the individualization of the readymade in Boite-en-valise, we can speak of a homogenization of the objects' different appearances in the "14 Readymades."

In the actual fabrication of these objects, the paradox of a remake after a model which had been declared an original-post facto-became even stronger. How could a three-dimensional remake of the urinal be produced after Alfred Stieglitz's frontal shot from 1917, without knowing what the object looked like in profile? What basis could there be for objects where no photo of the original had survived, e.g. for the typewriter cover "Pliant...de Voyage" or the Bottle Dryer? In fact, the multiple of the Bottle Dryer was produced after Man Ray's photo of the replica from 1936 (and in the meantime also lost), which Duchamp already had used for Boite-en-valise. ${ }^{8}$

As the multiples of the " 14 Readymades" were produced in editions of eight copies plus two artist copies, as well as two exhibition copies each, all in all we now have the very considerable number of 168 objects that now crowd museums. This is why the multiples have the largest impact on the 'public appearance' of the readymades in exhibitions. On the other hand, the two nonmodified readymade objects which have survived from the formative years of the concept are almost never seen in exhibitions: The art print "Pharmacy" selected and signed by Duchamp in Paris 1914 , today resides in an anonymous private collection. While the Comb, inscribed with a sentence by Duchamp in New York 1916 is part of the collection of the Philadelphia Museum of Art and due to the fragility of its inscription can no longer be loaned to any other venues. 
The same goes for the photographic representation of readymades in books or on the internet, where the prevailing reproductions are those of the multiples and not of the lost originals or other singular objects selected or approved by Duchamp later. This is why the diversity of existing forms has succumbed to a standardization 'after the fact'-so to say-in the second half of the readymade century.

The fundamental, often overlooked question in the discourse on Duchamp's readymade is: If we encounter one of these multiples from the 1964 edition e.g. the Fountain or the Bottle Dryer in an exhibition today, what do we actually see? In the case of Fountain: we see the three-dimensional reconstruction of a lost urinal, after the photograph by Alfred Stieglitz from 1917, after the section drawings that a technical draftsman based on this photo, cast in porcelain from these drawings by a manufacturer of sanitary goods in 1964 (Fig. 6.4).

In the case of the Bottle Dryer: we see the three-dimensional reconstruction of a lost object that has left no photographical record, after an idea by Duchamp from 1914, after a replica of this idea from 1936, after the photograph of this replica by Man Ray from that same year, and after the section drawings that a technical draftsman based on this photo, which was then produced from these drawings by Italian craftsmen in 1964 (Fig. 6.3).

The most detailed analysis of the collaboration between Marcel Duchamp and Arturo Schwarz in the production of these readymade multiples is Adina Kamien-Kazhdan's recent study Remaking the Readymade. ${ }^{9}$ Here Kamien-Kazhdan introduces for these works the "notion of alternate or shared authorship, transferring research and production from Duchamp to Schwarz." 10 Based on comprehensive material and correspondence available from the Galleria Schwarz archive (now at the Israel Museum, Jerusalem) and personal interviews with Arturo Schwarz, this book includes some relevant new information for Duchamp scholars. Interestingly, in March 1964, Schwarz still considered to buy off-the-shelf bottler dryers instead of having new ones produced after the Man Ray photograph. ${ }^{11}$ For the first time some 'making of' stories on Arredamenti Zaroli, the Italian manufacturer of these objects, are disclosed. This is especially interesting in regard to the technical drawings, executed by Dante Zaroli, from which the editioned replicas were produced. ${ }^{12}$ These blueprints were approved by Duchamp with his signature and have thus entered the universe of his readymades. In fact, these blueprints were presented for the launch of the multiples alongside the 14 readymades. ${ }^{13}$ Thus, in a series of international exhibitions which introduced these objects 
successfully to the artworld and the art market, the visitors were given clues regarding the 'making of' the so-called readymades. At the time, the multiples were almost never discussed from this viewpoint, rather, the prevalent theme of interviews that Marcel Duchamp gave on these occasions was the half-century old concept of the readymade as such-a topic at the center of interest for mid1960s art criticism.

While stating a "kind of scandalous inversion," in which "the survival of the lost original is dependent on the plural of the copy" Kamien-Kazhdan does not follow through the intrinsic artistic paradoxes of the hand-crafted remakes of consumer goods, which Duchamp readily admitted in interviews. ${ }^{14}$ One of the rare theoretical reflections on this topic by Séverine Gossart comes to the conclusion: "All in all, the Schwarz edition is a set of sculptures that wipe out the process of the readymades, even while reproducing their material appearance as faithfully as possible." ${ }^{15}$ But the farreaching consequences of this "inversion" for the contemporary representation of the readymades in exhibitions, print publications, and online images outlined above are not discussed in KamienKazhdan's study.

The basic principle of these objects, which had been selected, isolated, and withdrawn from their original practical use by Duchamp between 1914 and 1917 was now turned from its head to its feet. Contrary to a common belief, at the time of their conception, these objects had very little to no 'public appearances' in exhibitions or critical writing. ${ }^{16}$ It becomes apparent that the readymades had to be (re-)manufactured first, before they could be exhibited. Only as remakes did they become exhibits in the traditional sense. These limited-edition remakes of everyday objects were never made for use; they were always solely objects to be looked at in exhibitions. Only in the form of the remakes did the readymades become part of the art market. Perhaps we could even say that the art market was the true producer of these remakes.

This perfectly circular self-contradiction of his unique "selfappropriation" is declared by Duchamp to be part of his new artistic approach: "There is an absolute contradiction, but that is what is enjoyable, isn't it? Bringing in the idea of contradiction, the notion of contradiction, which is something that has never really been used, you see?"17 Some of Duchamp's friends and companions were skeptical about his cooperation with Galleria Schwarz. To John Cage the edition appeared like "a rather feeble attempt of a small businessman who tries to act in a businesslike way in a capitalist society." 18 And this was one of the moderate 


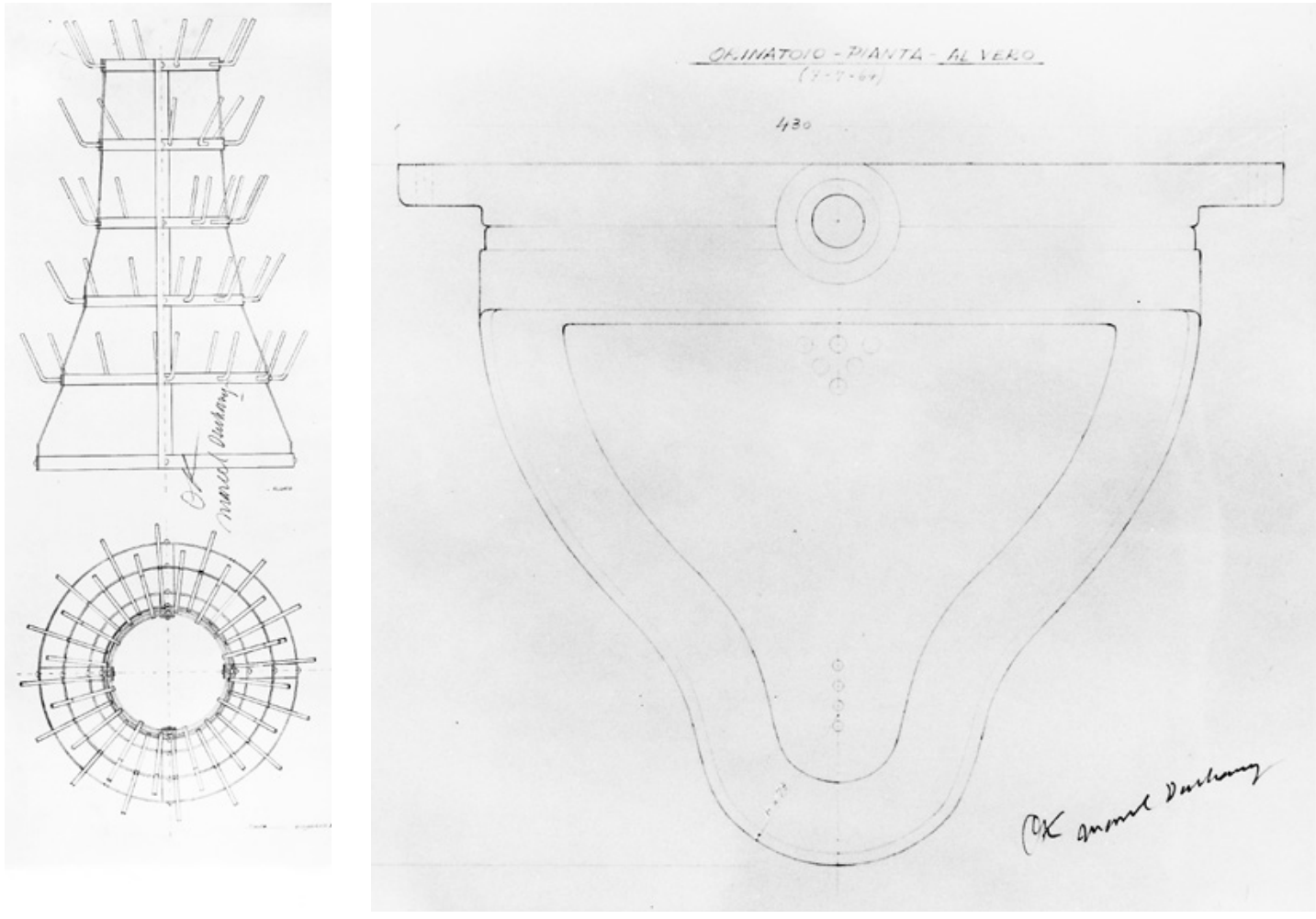

Fig. 6.3

Blueprint for the replica multiple of Bottle Dryer, 1964, signed "OK / Marcel Duchamp," Museu Coleção Berardo, Lisbon. @ Association Marcel Duchamp.

Fig. 6.4

Blueprint for the replica multiple of Fountain, 1964, signed "OK / Marcel Duchamp," BIJI Collection, Tokyo. @ Association Marcel Duchamp. 


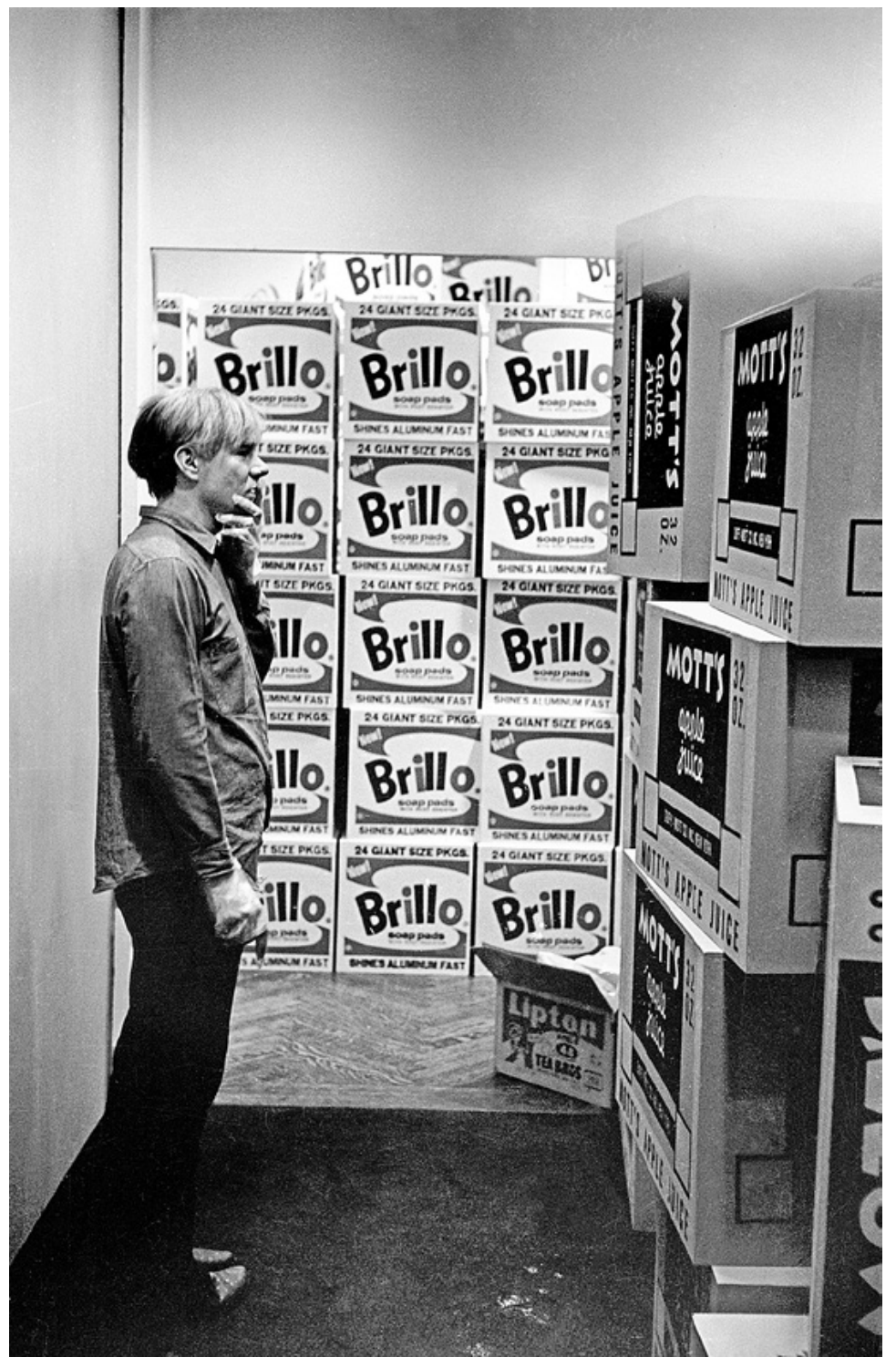

Fig. 6.5

Andy Warhol, Brillo Boxes, 1964. 
critiques of the time. But, as is often with Duchamp, looking back at these multiples, we realise that there is a new conceptual turn not to be overlooked. His "self-appropriation" resulted in a new type of works: no longer readymades, but post-readymades, they foreshadow a whole genealogy of related artistic concepts up to the present day.

\section{POST-READYMADES}

Aside from the edition of the readymades as multiples, we can see the year 1964 as a turning point from the readymade to the post-readymade in yet another respect. It is the year in which Andy Warhol first presented his Brillo Boxes: hundreds of them, stacked like in a supermarket, filled the exhibition space at their premiere in the Stable Gallery (Fig. 6.5). Comparing Warhol's Brillo Boxes to Duchamp's readymades has become commonplace in art theory due to the pertinent writings of Arthur C. Danto. An encounter with the Brillo Boxes in 1964 became the initial spark for Danto's decade-long work on a nonontological art theory. ${ }^{19}$ His analysis is often criticized for treating Warhol's boxes as if they were readymades, while in fact they were artifacts produced for the occasion. ${ }^{20}$ At the same time, both Danto and his critics ignore the far-reaching parallel between the Brillo Boxes and Duchamp's multiples of the readymades from the same year: Warhol's silkscreened wooden boxes, which look exactly like cartons that contain scouring pads, are also remakes of consumer goods. Aside from the size of the edition, the main difference from Duchamp is again the 'making of' aspect. Duchamp's remakes are real objects formed from the same materials as their long-lost progenitors, so they are even closer to utility objects. Warhol's Brillo Boxes are three dimensional pictures of these packages, they were produced in a similar fashion as his famous pop paintings. To put it short: We cannot pack anything into Warhol's remakes of Brillo boxes, while we can indeed shovel snow with the remake of Duchamp's snow shovel.

Regarding their manner of presentation, the situation is the opposite: the stacks of hundreds of Brillo Boxes at Stable Gallery were presented as if they were real, 'ready-made' cartons. Thus, Warhol underlined both their serial manufacture in his Factory studio as well as the commodity characteristics of art as a product. In contrast, the seriality of Duchamp's remade readymades remains invisible, especially when they are presented as single objects in specially designed displays. 
If the remakes of consumer goods by Warhol and Duchamp in 1964 mark the turning point from the readymade to the post-readymade, this turn concerns not merely aspects of their fabrication, but also has far-reaching consequences for artistic strategies in a commercial context. As Warhol's presentation of the Brillo Boxes at the Stable Gallery proves, the readymade principle can be translated into an art-market strategy. In contrast, Duchamp's approach to the readymade between 1914 and 1917 had opposed the dictates of self-repetition required by the art market: "It was really to get out of the exchangeability, I mean the monetization, one might say, of the work of art. I never intended to sell my readymades. So, it was really a gesture to show that one could do something without having, in the back of your head, the idea of making money through it." This is what Duchamp stated in an interview with Calvin Tomkins, which, probably not by sheer coincidence, also took place in 1964. When Tomkins repeated his question with some incredulity, Duchamp insisted: "Never. Never did I sell them." 21

Duchamp was completely aware that the concept of the readymades would change by selling their remade multiples. When an artist from the U.S. asked him to sign a bottle dryer he had accidentally found in the trash in 1964, Duchamp declined to do so in view of his contract with Schwarz, and then added: "But signature or no signature, your find has the same 'metaphysical' value as any other readymade, [it] even has the advantage to have no commercial value." 22

Following today's terminology, Duchamp's strategies concerning the readymade before 1917 can be seen as critique, ormore precisely - as an avoidance of the commodity character of art. In place of the commodification of art as a product, the readymades posit the product as art. With Duchamp's post-readymades from 1964, though, the readymades do become an art commodity. Thus, his strategy of self-appropriation can be seen as a forbearer to the self-commodification strategies of the readymade and the 'remaking' in the work of Elaine Sturtevant, Mike Bidlo, Sherrie Levine, and Jeff Koons, with continuing success on the art market. Interestingly, Levine and Koons also started out with pure readymades and then progressed into readymade remakes-as illustrated by Koons' early appropriation of an inflatable bunny (Inflatable Flower and Bunny [Tall White and Pink Bunny], 1979) versus the later replica of the same object in stainless steel (Rabbit, 1986). In a slightly different mode, Sherrie Levine sold 75 pairs of children's shoes she had bought 'ready-made' as part of her action 
Shoe Sale in 1977. For Two Shoes, an edition of multiples from 1992, she produced similar children's shoes herself in an edition of 135 pairs. ${ }^{23}$ "A refined version, handmade in Italy from softest leather and suede, retraces the artist's first steps," read the blurb by art magazine Parkett, which had commissioned the edition. ${ }^{24}$

\section{READYMADE CONTEMPORARY}

Today the pluralism of artistic practices that include the 'readymade' have exploded long past the idea of limiting the number of readymades, which had been so crucial for Duchamp. When the artist pointed out in 1965 that he did not want to establish a "school of the readymade," he was conscious of the fact that this already had happened. From the 1960s up to now, we can compile a voluminous compendium of readymade-like works and artistic positions-as illustrated by a series of exhibitions covering the second half of the 20th century. ${ }^{25}$

As an ironic tribute to the countless variants and derivatives of Duchamp's readymades, John Armleder collected the Readymades of the 20th Century (1997-2000) in a kind of readymade gesamtkunstwerk. The main title of the work contains a warning to fellow artists and curators-Don't Do It!-which expectedly remains without consequences: in the 21st century, too, we encounter ever more artistic practices that use the "already made."

The expansion of the readymade principle in recent art continues the pluralism, which was already part of Duchamp's work and cannot be brought under a common denominator. Nevertheless, two strands can be discerned: on the one hand, the ongoing development of practices of the "already made" without an explicit reference to Duchamp's readymades; on the other, readymades after readymades, art-historical references or revisions of Duchamp's works.

The readymades after readymades by Sherrie Levine (Fountain [After Duchamp], 1991) and Elaine Sturtevant (Duchamp Fresh Widow, 1992-2012) do not present ready-made objects that were selected by the artist, but, similar to Duchamp's multiples, they were produced in small limited-edition series to the artist's specifications and then offered for sale. Interestingly, both artists, on different occasions, presented a complete edition of their multiples as temporary ensembles. Levine first showed Fountain (After Duchamp) in 1991 at Mary Boone Gallery, New York, with three copies from the edition of multiples simultaneously on view. ${ }^{26}$ At the following museum exhibition in 1991-1992, the complete run of the six copies of the bronze sculptures were shown side by side 


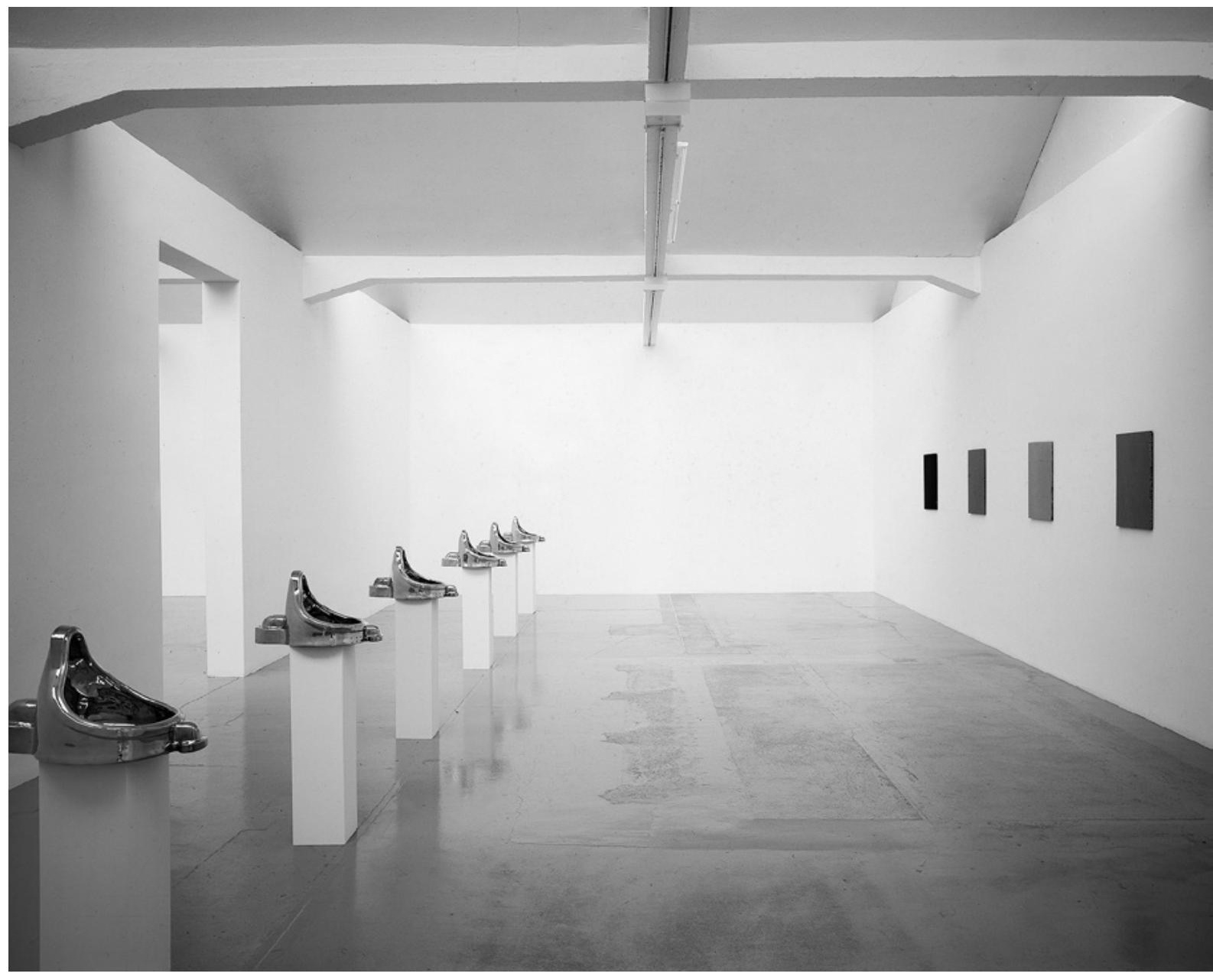

Fig. 6.6

Sherry Levine, Fountain (After Duchamp), 1991 (sometimes titled Fountain [Madonna]). Installation View, Sherrie Levine, Kunsthalle Zürich, 1991.

@Photo: Alexander Troehler. 
(Fig. 6.6). ${ }^{27}$ Sturtevant exhibited the full edition of Duchamp Fresh Widow (1992) in nine copies at the Moderna Museet Stockholm in 2012.28 In these exhibitions, both Levine and Sturtevant presented the multiples as multiples (after readymades). Thus, they countered the illusion of the singular readymade, which had established itself through the classic museum presentations of Duchamp's works. A similar effect in Duchamp's case would of course be possible if all eight copies of the multiple edition from 1964 were shown simultaneously. 29

As some copies were sold, the ensemble dissolved soon after the exhibitions, and consequently, the multiples by Levine and Sturtevant were presented as unique exhibits just like Duchamp's readymades. While we have already discussed the aspect of Duchamp's post-readymades and Warhol's Brillo Boxes masking or respectively revealing the commodity status of the art "product," Levine's and Sturtevant's readymades after readymades give a whole new twist to the story: the art market's reinterpretation of the readymades now itself becomes a topic of artistic and market "speculation," which brings us to the next level of ambivalence between affirmation and critique. ${ }^{30}$

The historical reception of the readymade and its various developments has itself become a theme for artistic approaches at the end of the "Readymade Century." The conflict between singularity and pluralism, which has already been laid out in Duchamp's work, is explored for example in ensembles by Bethan Huws and Saâdane Afif. Huws presents a room installation of 88 bottle dryers in different sizes and forms under the suggestive title Forest (2008-2009). ${ }^{31}$ As an ensemble of meta-readymades, Forest evokes Duchamp's lost object while making it disappear behind gradations of differences. Their patina and clear signs of usage lend each of the pieces a sense of their own story and individuality, and so they become objects of contemplation. In this sense, Forest deliberately contradicts Duchamp's quest for an aesthetic indifference. ${ }^{32}$

With his Fountain Archives (2008-2017), Saâdane Afif has built an "imaginary museum" of reproductions, which will finally comprise 1001 images of the titular readymade collected from various publications. ${ }^{33}$ This archive, organized in accordance with a strict classification system, reflects the wide distribution of Duchamp's Fountain, which today has become an icon of modernism. At the same time, the visible differences between the objects and their modes of representation within the illustrations reinforce the absurdity of a search for their "authentic" (pre-)image 
or origin. The Fountain Archives portray the "Readymade Century" as a century of reproduction: a urinal that was never exhibited, that was soon lost and only once photographed, has caused a steadily growing avalanche of illustrations.

On another level, this process also takes hold of Saâdane Afif's own artistic project: any published appraisal of the Fountain Archives leads to a growing number of the work's illustrations. These new images themselves add to the archive, to occupy a specially created "augmented" section within it. ${ }^{34}$ This project albeit ironical, also has an art historical relevance: it aims to create the most comprehensive resource for the history of reproduction of a 20th century work of art. The illustrations taken out of the books will become a source for Afif's new artist book, all 1001 pages of which will be distributed across the art world (because the framed pages are sold to collectors, while the books remain part of the project).

In a playful way, Fountain Archives opens up feedback loops between theory and practice-as is the case with my own book Readymade Century which becomes part of the archive in the "augmented" section: while the text of the book attempts to reflect on this process, the book will become part of an artwork that the text is describing. These "epistemic" constellations by Saâdane Afif play with the difference between the imaginary (the readymade as concept) and the real (the readymade as physical object, as printed reproduction of this object). At the same time, they thematize the idolization and fictionalization of Duchamp's readymades throughout the history of their reception, as well as the intangibility of a supposed "original," which recedes further and further with its multiplications.

This section's title 'Readymade contemporary' is meant to (re-)connect two separate tracks of the ongoing discourse. On the one hand, the highly specialized 'Duchamp science' (of which this essay is also a part) still brings relevant new insights, which, arguably, matter only to specialists in the field. On the other hand, the ongoing currency of the readymade principle, reaching far beyond Duchamp's work, is based on the continuing state of tension between the two meanings of the word readymade/readymade, between industrial and artistic productionor, more generally, between the unabated quest for individuality and the formatting of that quest by the capitalist production of commodities, which is ever progressing since Duchamp's time. In this sense, it is possible to approach the Readymade Century as an ongoing process of hybridization and conflict, a process which does not end after Duchamp. 
How can we not fall back the current state of research on Duchamp, and at the same time acknowledge the increasing relevance of the questions that the readymade posed a century ago, stretching far beyond the specialist research on the artist? At the international symposium Duchamp's Readymades: A Reevaluation in Aarhus 2018, the possibility of re-connecting these discourses became tangible, e.g. when the concept of "self-appropriation" appeared in two papers independently and under different contextualizations. ${ }^{35}$

Today, most artistic practices of the 'already made' do not refer explicitly to Duchamp's readymade, nor use the term, but investigate aspects in our contemporary art world and commodity culture. Art becomes part of a feedback loop: on the one hand, it explores or critiques the global circulation of goods and "cognitive capitalism," on the other, it serves the market capitalization of ideas and objects by "rebranding the readymade" (Martha Buskirk) as art merchandise. ${ }^{36}$ The 2017 symposium Readymade Century investigated these resonances and interconnections between the 'ready-made' commodity and the artistic 'readymade' practice in the context of circulation of goods in the age of globalization and just-in-time and on-demand (post-ready-made) production. ${ }^{37}$ Such investigation includes the new question marks in intellectual property and the ambivalent status of ethnological objects that are removed from their everyday use value and are given exhibition value as unique items. In this pursuit, the radical nature of Duchamp's original gesture can be viewed against the background of categorical shifts and new aesthetic possibilities of a postindustrial, post-digital, and post-colonial present. 
1 Jean Antoine, “An interview with Marcel Duchamp: ‘I believe that a picture, a work of art, lives and dies just as we do..., ," The Art Newspaper, no. 27, April 1993, online at: http://www.theartnewspaper.com/articles/ An-interview-with-Marcel-Duchamp/29278.

2 Marcel Duchamp, "Apropos of 'Readymades,'” lecture at the symposium The Art of Assemblage, Museum of Modern Art, New York, October 19, 1961, first printed in: Art and Artists, London, vol. I, no. 4, July 1966, 47.

3 Arturo Schwarz, The Complete Works of Marcel Duchamp (New York: Delano Greenridge Editions, 3rd ed., 1997), 369.

4 Ibid., 306. Ulf Linde's handmade single replicas of the readymades served as models for the edition of multiples produced by Galleria Schwarz. See the extensive research on Linde's readymade remakes by Paul B. Franklin "Exposing Duchamp in Sweden," in: Étant donné no. 11 (Paris 2016): 94-141.

5 See Duchamp's letter from 1964 in: Francis M. Naumann, Marcel Duchamp, The Art of Making Art in the Age of Mechanical Reproduction (Ghent and New York: Ludion Press, 1999), 245.

6 In the first edition of Arturo Schwarz's Collected Works from 1969, we still find the following information for several of the objects that were not documented in photographs before they became part of the edition of multiples in 1964: "First full scale-replicas issued under the direct supervision of Duchamp on the basis of a blueprint derived from photos of the lost original" (no. 219, Bottle Dryer; no. 240, Traveler's Folding Item). This is later corrected, so that in the edition of 1997 we read under no. 342, Traveler's Folding Item: "No photograph of the original Readymade exists." And on the corresponding multiple: "Produced under the artist's supervision after the Boîte-en-valise reproduction." Martha Buskirk points out these changes in the wording of Schwarz's Complete Works between the different editions in 1969 and 1997: Martha Buskirk, The Contingent Object of Contemporary Art (Cambridge and London: MIT Press, 2003), 70.

7 Schwarz, The Complete Works of Marcel Duchamp, 595-598 and 601-605.

8 For a full genealogy of the Bottle Dryer see: Dieter Daniels, “Marcel Duchamp's Porte-bouteilles. À la recherche du readymade perdue", in: Marcel Duchamp. 100 Questions. 100 Answers, exhibition catalogue Staatsgalerie Stuttgart, 2018, ed. Susanne M.I. Kaufmann.

9 Adina Kamien-Kazhdan, Remaking the Readymade: Duchamp, Man Ray, and the Conundrum of the Replica (London and New York: Routledge, 2018).

10 Ibid. 166.

11 Ibid. 160.

12 Ibid. 159.

13 Ibid. 153. See also the forthcoming publication of my essay: Dieter Daniels, Stop Over in Hannover: Marcel Duchamp, même in der Kestnergesellschaft 1965, in: Kestnerbuch, 100 Jahre Kestner Gesellschaft, (Hannover 2019).

14 Ibid. 14.

15 Séverine Gossart, "Des Originaux dérivés. La situation des ready-mades de Marcel Duchamp dans les années
1950-1960", in: G. Ulrich Großmann and Petra Krutisch (eds.), The Challenge of the Object, 33rd Congress of the International Committee of the History of Art, Congress Proceedings-Part 1 , (Nuremberg, 2013), 160.

16 See: Dieter Daniels, Readymade Century (Leipzig: Spector Books, 2019), 95-110.

17 "Marcel Duchamp Talking about Readymades" (Interview with Phillipe Collin, 1967), in: Marcel Duchamp, ed. by Museum Jean Tinguely, (Basel and Ostfildern: Hatje Cantz, 2002), 38.

18 John Cage quoted in: Thomas Girst, The Duchamp Dictionary (London: Thames and Hudson, 2014), 64. See the whole entry "edition of 1964-65" for more comments by contemporaries of Duchamp.

19 Danto proceeds from the fact "that the almost laughable inapplicability of philosophical definitions of art to art itself has been explained, by the few who perceived the inapplicability as a problem, as stemming from the indefinability of art." (Arthur C. Danto, The Transfiguration of the Commonplace, (Cambridge, MA, 1981), vii.) I am sympathetic to Danto's theory especially since he admits to a "philosophical intoxication" prompted by his encounter with Warhol's Brillo Boxes in 1964, which still had its effect when he wrote this text published in 1981 (ibid., vi), and would continue to inspire his investigations up to his last book, What Art Is (New Haven: Yale University Press, 2013).

20 Juliane Rebentisch, Theorien der Gegenwartskunst (Hamburg: Junius, 2013), 122.

21 Calvin Tomkins, Marcel Duchamp: The Afternoon Interviews (New York: Badlands Unltd, 2013), 26.

22 Letter to Douglas Gorsline, in: Naumann, The Art of Making Art in the Age of Mechanical Reproduction, 245.

23 See the interview with Sherrie Levine in: Martha Buskirk and Mignon Nixon (eds.), The Duchamp Effect: Essays, Interviews, Round Table (Cambridge and London: October Books, 1996), 178.

24 Online at http://www.parkettart.com/editions/32edition-levine.html.

25 For an extensive list see: Daniels, Readymade Century, 173-175.

26 Sherrie Levine: Fountain, Mary Boone Gallery, New York 1991, catalog with a text by Bruce Ferguson. Cf. the review by Roberta Smith, "Art in Review," New York Times, May 24, 1991. Thanks to Grady O'Connor, David Zwirner Gallery, New York, for the suggestion.

27 Sherrie Levine, Kunsthalle Zürich 1991-1992, traveling to: Westfälisches Landesmuseum, Münster; Rooseum Center for Contemporary Art, Malmö; Hôtel des arts, Paris.

28 Elaine Sturtevant first produced Duchamp's Fresh Widow in $\mathbf{1 9 9 2}$ as a replica, then in $\mathbf{2 0 1 2}$ as an edition of nine copies for the exhibition Sturtevant: Image over Image, Moderna Museet, Stockholm 2012 (email to the author by Fredrik Liew, curator of the exhibition at Moderna Museet, June 1, 2016).

29 Germano Celant tried a comparable curatorial experiment when he exhibited several exemplars of the same object in his retrospective on the history of the multiple. He included two copies each from the 1964 edition of Duchamp's readymades as multiples (The Small Utopia: Ars Multiplicata, Fondazione Prada, Venice 
2012). Four different versions of the Bottle Dryer were first shown together at the exhibition Übrigens sterben immer die anderen: Marcel Duchamp und die Avantgarde seit 1950, Museum Ludwig, Cologne 1988 (exhibition and catalog by Dieter Daniels and Alfred M. Fischer). This constellation consisted of three versions of the Bottle Dryer signed by Duchamp (from 1921, 1960, and a multiple from 1964) as well as a new specimen from the Bazar de l'Hôtel de Ville in Paris, where Duchamp had bought his first Bottle Dryer in 1914. The exhibition catalog illustrates for the first time as many as eight different versions of the Bottle Dryer, each legitimized by the artist (ibid., 78f). Contrary to the presentations of Levine, Sturtevant, and Celant, the exhibition and catalog clarified differences in form and size, to deconstruct the idea of the singular, self-identical object.

30 Cf. the panel discussion "Readymade Market" at the symposium The Readymade Century at Haus der Kulturen der Welt, Berlin, October 12-13, 2017, www. hkw.de/readymade.

31 Bethan Huws, Forest, Cologne 2015 (exhibition at Staatliche Kunsthalle, Karlsruhe 2015-2016).

32 Bethan Huws comments: "The difficulty of doing anything 'new' in the sense that always 'something' is pre-existing - we make the 'new' from the 'old."' (Conversation with the author, Berlin, December 3, 2016.)

33 See: www.thefountainarchives.net; Saâdane Afif, Fontaines, Brussels 2014.

34 http://thefountainarchives.net/year/augmented.

35 David Joselit introduced the concept of selfappropriation for the aboriginal artist, producing acrylic dot paintings for the art market.

36 See: Martha Buskirk, Creative Enterprise: Contemporary Art between Museum and Marketplace (New York: Bloomsbury, 2012), 201-262.

37 The Readymade Century, International Symposium, HKW, Haus der Kulturen der Welt, Berlin, October, 12-13, 2017, curated by Dieter Daniels in collaboration with Annette Bhagwati. With contributions by Saâdane Afif, Inke Arns, Kader Attia, Annette Bhagwati, Lars Blunck, Martha Buskirk, Dieter Daniels, Simon Denny, Sebastian Egenhofer, Famed (Sebastian Kretzschmar, Jan Thomaneck), Thomas Girst, Isabelle Graw, Katja Kwastek, Oliver Laric, Sven Lütticken, Benjamin MeyerKrahmer, Olaf Nicolai, Margareta von Oswald, Matthew Plummer-Fernandez, Annette Tietenberg, Gesine Tosin, Tobias Vogt, see: www.hkw.de/readymade. 